\title{
Clinical guidelines on pediatric asthma exacerbation in emergency department, a narrative review
}

\author{
Shabahang Jafarnejad, Hamidreza Khoshnezhad Ebrahimi \\ Department of Emergency Medicine, School of Medicine, Iran University of Medical Sciences, \\ Aliasghar Children Hospital, Tehran, Iran \\ This article is distributed under the terms of the Creative Commons Attribution Noncommercial License (CC BY-NC 4.0) which permits \\ any noncommercial use, distribution, and reproduction in any medium, provided the original author(s) and source are credited.
}

\begin{abstract}
Asthma has been known as a prevalent chronic-type inflammatory disease in children, because of their narrower respiratory airways. The present study aimed to identify guidelines for children asthma treatments. Extensive research was conducted on biomedical and pharmacological bibliographic database PubMed, EMBASE, MEDLINE, LILACS database, global independent network of Cochrane, Science Direct and global health library of Global Index Medicus. A comprehensive literature review was carried out using the terms Pediatric Asthma, epidemiology, management, and related clinical guidelines published from 2000 to 2019. After the primary assessment, quick diagnosis, clinical practice guidelines are useful tools for proper management of pediatric Asthma. By setting proper guidelines for this particular population, a higher improvement in quality of management of of pediatric Asthma is expected. Given the differences between the recommendations arisen by BTS/SIGN and NICE guidelines, critical comparison of the evidence-base guidelines provide suggestions that have more in common than what might seems at the first glance. The analysis of the variations presented in the present article will assist clinicians to make accurate decisions regarding their patients.
\end{abstract}

Key Words: Pediatric asthma, child health, Emergency Department, emergency care, clinical guidelines

Eur J Transl Myol 30 (1): xx1-xx8, 2020

The Emergency Department (ED) duty is the care of critically and acutely patients and the Pediatric ED is specialized for infants, children, and teenagers. The Pediatric EDs visits is approximately $25 \%$ of all emergency visits. ${ }^{1}$ Asthma is a respiratory disease caused thousands of deaths every year in the U.S. ${ }^{1}$ Children, because of narrow airways and inhaling more air than adults, are the most exposed to asthma. ${ }^{2}$ It is estimated that $9 \%$ of all children currently have asthma in this country. ${ }^{3}$ A conventional cause of referrals to emergency wards has constantly been asthma among children. According to a formal statistics, pediatric asthma exacerbations occupy 1.8 million visits to emergency wards. ${ }^{4}$ Asthma carries a significant economic loss due to chronic effects. Uncontrolled asthma causes essential care of patients frequently in an ED setting. ${ }^{5}$ The broad concern exists about asthmatic treatment in patients; there are several guidelines on management of asthma for both adults and children. In 1990 for the first time, The British Thoracic Society (BTS) made guidelines for asthma. Scottish Intercollegiate Guideline Network (SIGN) as a first collaborative guideline was published in
2003 by using evidence-based medicine methodology. ${ }^{6}$ After such guidelines became a foundation handling of asthma in the United Kingdom, the related updates are regularly released every 18-24 months. In 2016, the most recent guideline of BTS/SIGN on management of asthma was released. ${ }^{6}$ The national guidelines for emergency care of asthma among children, containing prescription of oral corticosteroids and reduction of ancillary examination including the chest radiograph has been published. ${ }^{7}$ For example, the NAEPP Program which stands for National Asthma Education and Prevention Program, suggested Primary Care Provider (PCP) and systemic care toward children with asthma. The National Institute for Health and Care Excellence (NICE) ordered guidelines for the diagnosis, monitoring, and administration of chronic asthma but after that now some national guidelines with some striking differences exist for at least England regards of similarities and differences in these guidelines can help to clinical care of asthma patients. Mainly the asthma exacerbations management at an emergency ward is Bronchodilator and systemic corticosteroid therapies. This review will focus on 


\section{Pediatric asthma exacerbation in emergency department}

Eur J Trans1 Myol 30 (1): xx1-xx8, 2020

international and national guidelines for pediatric asthma in an emergency ward/department and children's asthma treatment based on these guidelines in EDs and home of discharged patients. ${ }^{6}$

\section{Methods}

Extensive research was conducted on some biomedical and pharmacological bibliographic database of life sciences such as PubMed, EMBASE, MEDLINE, LILACS database, global independent network of Cochrane, Science Direct and global health library of Global Index Medicus (GIM). By referencing these databases, a comprehensive literature review was carried out through combining numerous recent studies in terms of Pediatric Asthma, epidemiology, management, and related clinical guidelines according to articles published from 2000 to 2019 . Totally 284 articles were checked briefly which about 42 of them were deleted due to less related content to the objective of the study. Finally, after deleting some other articles with subjective weakness and adding several other articles through new databases, 30 articles were separated for extended detailed review. For reaching the objectives of this study, the candidate articles in terms of evidence-based medicine (EBM), management of pediatric asthma in emergency departments, asthma, child health, emergency care, and clinical practice guidelines were identified.

\section{Pediatric Asthma epidemiology}

The asthma prevalence has been increased in developed countries during the Twentieth century mainly in children. As a result, in the 1990s, a series of international epidemiological studies on children's Asthma (e.g. International Study of Asthma and Allergies in Childhood (ISAAC) has been performed. ${ }^{8-10}$ These studies indicated asthma as a globally-dispersed chronic disease with significant prevalence diversity around the world. It is currently widely-accepted that prevalence of asthma has peeked in developed countries; this is while, such an increase may be also constant in low and midincome countries. ${ }^{6,11,12}$ Asthma is a non-communicable and globally disease that causes high rate of morbidity as well as mortality in serious cases. The prevalence of pediatric asthma is more seen among boys. The identification among this disease and wheeze exacerbations is very hard, especially in young children.
Wheeze is diagnosed in a third of children with similar symptom. $\mathrm{s}^{6,13}$ Exacerbations of periodic wheeze happen in many children that must be diagnosed as viral-induced wheeze more than asthma, so asthma treatment results would be different in this group. The BTS audit (2015) indicated the children between one and five years old mostly admitted with asthma/wheezy exacerbations. Their audit demonstrates most children needed hospitalization for less than one day and that approximately $40 \%$ were administered only in the ED and next demobilized to house. Also, they indicated smoking as a risk factor which is preventable to a large extent. According to the reports issued by National Review of Asthma Deaths (NRAD), nearly 25,000 children with asthma were hospitalization in two years (2011-2012). Many risk factors exist that related to asthma exacerbations including passive tobacco smoking, respiratory tract's viral infections, allergen disposal, age, season, air pollution, gender, and lack of immunizations or imperfect immunizations. Asthma exacerbations have reached their peak in September because of the incidence of a viral illness this month. ${ }^{6,14}$ Emergency wards/departments (EDs) are for care of patients suffering from critical problems. The area for children's emergency medicine is just for infants, childhood, and teenagers care. ${ }^{15}$ The pediatric EDs meeting are nearly $25 \%$ of all referring to emergency. Studies indicate in 10 years (from 1996 to 2006) the pediatric EDs visits number increased by $3 \%$ each year. $30 \%$ of pediatric emergency visits are No emergent cases, that this no emergent patient requires immediate medical care less than 12 hours. ${ }^{4,16,17}$ The presentation of children asthma in clinics generally contains dry cough, rale, and breathlessness. Worsening of these symptoms indicates an exacerbation of asthma. ${ }^{18}$ These clinical symptoms may relate poorly to asthma exacerbation. So, extreme asthma exacerbation in children can seem to be well deceitfully. Exacerbations of asthma based on the clinical presentation can grade to mild, moderate, acute and life-threatening. Measurement such as saturation of oxygen, respiratory and peak expiratory flow rate (PEFR) can be performed. ${ }^{19}$ Children with signs similar to asthma that usually refer to EDs are summarized in table 1. Diagnosis of asthma is based on those signs and investigate history of disease. ${ }^{6}$

\section{Table 1. Asthma risk factors}

1. Preschool children with viral-induced wheeze

2. Children presenting for the first time with a new onset of asthma signs and symptoms.

3. Children with an established diagnosis of asthma that is in exacerbation.

4. Children presenting with asthma-related issues such as not having a replacement inhaler or inappropriate inhaler techniques causing poor response to inhalers administered at home.

5. Children presenting with status asthmatics, characterized by severity and lack of response to repeated doses of inhaled bronchodilators, (severe or life threatening) who may need resuscitation. 


\section{Pediatric asthma exacerbation in emergency department}

Eur J Transl Myol 30 (1): xx1-xx8, 2020

\section{Emergency Department guidelines}

Asthma-guideline may improve patients' clinical care. ${ }^{5}$ Broading distribution of guidelines systems may help to treat asthma. ${ }^{20}$ National Heart, Lung, and Blood Institute (NHLBI) emergency-heightening administration guidelines treatment with lung-function testing, peakflow readings, and oxygen saturation directly. ${ }^{21,22}$ This guideline cover a diagram for asthma flow which gives common fundamentally and needs local personalization to account medications and scoring for personal ED varieties. The guidelines of NHLBI indicate early asthma diagnosis symptoms and stratified treatment with acute severity. ${ }^{23}$ Most recently, guidelines of National Asthma Education and Prevention Program (NAEPP) have been updated in terms of chronic asthma care. ${ }^{24}$ BTS/SIGN (2016) guidelines are summarized in table 2 for each intensity level of asthma but those guidelines must be utilized carefully when do not exist prior asthma signs in childhood below the age of two years. These guidelines are typically not utilized to asthma management for children younger than one year; therefor asthma diagnosis in this age is commonly performed with the help of a specialist respiratory pediatrician. ${ }^{25}$

The asthma guidelines time nature makes more challenges to track. A computerized/automated system could help to reduce many challenges that accrue in this line. Additionally, there are recommendations of these guidelines such as preparation of an Asthma Action Plan (AAP) and adding an ICS administration for a discharged patient after acute treatment in the emergency ward. ${ }^{21}$

The NICE guideline suggests utilizing of the MART regimen for youngs 5-16 years old. Bisgaard et al that showed lower attacks in children using MART though it is acknowledged that no MART is allowed for usage in kids at the time of publication. ${ }^{24}$

\section{Clinical guidelines in Emergency Departments for children suffering with asthma}

Treatment of children suffering with asthma in emergency wards needs analysis and organization of the severity of asthma and the excellent performance of a coordinated provider team. Acute asthma symptoms in patients' treatment in EDs should be identified early. The accuracy of the airway severity obstruction and response to therapy should be evaluated. Frequent reevaluation by asthma-scoring, peak-flow and oxygen-saturation measurement indicates initial asthma-severity rating of the patient. Decisions on care are recommended to be adjusted to a new level of severity, resulting in a disposition decision after each valuation. ${ }^{6,26}$

Standardized care in a busy area like an emergency ward could be challenging. To provide a suitable treatment various asthma guidelines exist. These guidelines have general ordering about medications and treating clinicians. The primary treatment for those cases experienced a mild exacerbation includes a Single Short Acting $\beta$-Agonist (SABA) inhalation. ${ }^{6,27}$ For moderateto-severe exacerbations of asthma, inhaling of SABA, systemic corticosteroids and ipratropium bromide are indicated. The patients requiring multiple $\beta$-agonist treatments and corticosteroids should be visited over a specific period after the primary treatment to investigate whether more treatment is required or not. ${ }^{6,28}$

There is obvious proof that is basic for the primary treatments utilized for pediatric asthma exacerbations; however, more limited evidence exists for second-line treatments, as BTS/SIGN 2016 guidelines (Table 2). The consequences of the disease and checkup must not be affected by the quick treatment for acute asthma in children. ${ }^{29,30}$ Huge flow oxygen utilizing a snugly-fitting face mask must be utilized in children with lifethreatening asthma. The breathed $\beta 2$ agonist salbutamol

Table2. The intensity of exacerbation for children older than five years, derived from the Sheldon et al. ${ }^{6}$

\begin{tabular}{|c|c|c|}
\hline » Oxygen saturations $\geq 92 \%$ & » Oxygen saturations $<92 \%$ & $»$ Oxygen saturations $<92 \%$ \\
\hline $\begin{array}{l}\text { »Peak expiratory flow rate (PEFR) } \\
>50 \% \text { best or predicted }\end{array}$ & » PEFR $33-50 \%$ best or predicted & $\begin{array}{l}\gg \text { PEFR }<33 \% \text { best or } \\
\text { predicted }\end{array}$ \\
\hline \multirow{3}{*}{$\begin{array}{l}\text { »No features of acute/life- threatening } \\
\text { asthma }\end{array}$} & » Unable to complete sentences & \multirow{3}{*}{$\begin{array}{l}\text { » Silent chest } \\
\text { »Cyanosis } \\
\text { » Poor respiratory effort » } \\
\text { Hypotension } \\
\text { » Exhaustion } \\
\text { »Confusion }\end{array}$} \\
\hline & $\begin{array}{l}\text { » Heart rate: } \\
>125 / \text { minute }(>5 \text { years }) \\
>140 / \text { minute }(1-5 \text { years })\end{array}$ & \\
\hline & $\begin{array}{l}\text { » Respiratory rate: } \\
>30 \text { breaths/minute }(>5 \text { years })>40 \\
(1-5 \text { years })\end{array}$ & \\
\hline
\end{tabular}


Table 3. Medicines for pediatric asthma exacerbations

\begin{tabular}{|c|c|c|c|c|}
\hline \multirow[t]{3}{*}{ Salbutamol } & $\begin{array}{l}\text { Inhaled, } \\
\text { aerosol }\end{array}$ & $\begin{array}{l}\text { » Two to ten puffs: each puff is inhaled } \\
\text { separately, repeat every } 10-20 \text { minutes or } \\
\text { as required, use a large volume spacer } \\
\text { » Use a snug-fitting face mask in children } \\
\text { under three years } \\
\text { » One puff is equivalent to } 100 \mathrm{mcg}\end{array}$ & $\begin{array}{l}\text { Mild to moderate } \\
\text { asthma }\end{array}$ & \multirow{3}{*}{$\begin{array}{l}\gg \text { agonist } 2 \\
\text { » Reverse air-flow } \\
\text { obstruction } \\
\text { » Onset of action } \\
\text { less than five } \\
\text { minutes } \\
\text { » Peak action 20- } \\
60 \text { minutes } \\
\text { Duration 4-6 } \\
\text { hours }\end{array}$} \\
\hline & $\begin{array}{l}\text { Nebulised, } \\
\text { driven by } \\
\text { oxygen }\end{array}$ & $\begin{array}{l}\text { One month to four years: } \\
\text { » } 2.5 \mathrm{mg} \text { every } 20-30 \text { minutes or when } \\
\text { required } \\
5-11 \text { years: } \\
\text { » } 2.5 \text { to } 5 \mathrm{mg} \text { every } 20-30 \text { minutes } \\
12-17 \text { years: } \\
\text { » } 5 \text { mg every } 20-30 \text { minutes } \\
\text { If improving: } \\
\text { » Slow doses to } 1-2 \text { hourly, then } 2-4 \\
\text { hourly }\end{array}$ & $\begin{array}{l}\text { Moderate, severe } \\
\text { or life-threatening } \\
\text { oxygen } \\
\text { saturations }<92 \%\end{array}$ & \\
\hline & $\begin{array}{l}\text { Intravenous } \\
\text { injection (IV) } \\
\text { (second line) }\end{array}$ & $\begin{array}{l}\text { Single bolus dose: } \\
» 1-23 \text { months: } 5 \mathrm{mcg} / \mathrm{kg} \text { over five mins } \\
\text { » } 2-17 \text { years: } 15 \mathrm{mcg} / \mathrm{kg} \text { over five minutes }\end{array}$ & $\begin{array}{l}\text { Severe asthma } \\
\text { unresponsive to } \\
\text { initial nebulised } \\
\text { therapy }\end{array}$ & \\
\hline Prednisolone & Oral & $\begin{array}{l}\text { One month to } 12 \text { years old: } \gg 1 \text { to } 2 \mathrm{mg} / \mathrm{kg} \\
\text { once daily } \\
\text { (maximum per dose } 40 \mathrm{mg} \text { ) for up to three } \\
\text { days, longer if required } \\
12-17 \text { years: } \\
\text { » } 40-50 \mathrm{mg} \text { daily for three to five days }\end{array}$ & $\begin{array}{l}\text { Moderate, severe } \\
\text { or life-threatening }\end{array}$ & $\begin{array}{l}\text { »Corticosteroid } \\
\text { » Reduces airway } \\
\text { inflammation }\end{array}$ \\
\hline $\begin{array}{l}\text { Ipratropium } \\
\text { bromide }\end{array}$ & Nebulised & $\begin{array}{l}\text { One month to one years: } \\
\text { » } 250 \mathrm{mcg} \text { every } 20-30 \text { minutes } \\
\text { for first two hours, then } 250 \mathrm{mcg} \text { every } 4- \\
6 \text { hours as required } \\
12 \text { to } 17 \text { years: } \\
\text { » } 500 \mathrm{mcg} \text { every } 4-6 \text { hours as required }\end{array}$ & $\begin{array}{l}\text { Severe or life- } \\
\text { threatening }\end{array}$ & $\begin{array}{l}\text { » Anticholinergic } \\
\text { »Onset of action } \\
20-30 \text { minutes }\end{array}$ \\
\hline Aminophylline & $\begin{array}{l}\text { IV } \\
\text { (second line) } \\
\text { (patient must } \\
\text { not be on oral } \\
\text { maintenance } \\
\text { theophylline) }\end{array}$ & $\begin{array}{l}\text { 12-17 years: } \\
\text { » } 500-700 \mathrm{mcg} / \mathrm{kg} / \mathrm{hr} \text {, adjusted to } \\
\text { plasma-theophylline concentration }\end{array}$ & $\begin{array}{l}\text { Severe or life- } \\
\text { threatening } \\
\text { resistant to } \\
\text { maximum } \\
\text { bronchodilator } \\
\text { and steroid } \\
\text { therapy }\end{array}$ & $\begin{array}{l}\text { Decreases } \\
\text { airway } \\
\text { inflammation }\end{array}$ \\
\hline $\begin{array}{l}\text { Magnesium } \\
\text { sulphate }\end{array}$ & $\begin{array}{l}\text { IV } \\
\text { (second line) }\end{array}$ & $\begin{array}{l}\text { 2-17 years old: } \\
\text { » } 40 \mathrm{mg} / \mathrm{kg} \text { (maximum per dose } \\
2 \mathrm{~g} \text { ) to be given over } 20 \text { minutes }\end{array}$ & $\begin{array}{l}\text { Severe or life- } \\
\text { threatening and } \\
\text { responding } \\
\text { poorly to first- } \\
\text { line treatments }\end{array}$ & $\begin{array}{l}\text { Relaxes smooth } \\
\text { muscle }\end{array}$ \\
\hline
\end{tabular}

is the initial therapy in children above two years. $\beta 2$ agonists do quickly and we can observe results after four to six hours. ${ }^{31}$ Answer to this kind of treatment could be observed utilizing saturations of oxygen and advances in clinical investigations, including normalizing of heart, rate of respiratory, and saturations of oxygen. $\beta 2$ agonists are supplied through a pressurized metered-dose inhaler (PMDI). Weak answer to $\beta 2$ agonists needs further reevaluations. ${ }^{31}$ In an online survey conducted in the UK from 183 emergency clinicians, Lyttle et al. indicated that inhaled salbutamol was used by all patients at emergency wards, $63.9 \%$ of them had used nebulized salbutamol meanwhile patients were hypoxic at presentation and PMDI, in case of acceptable saturations. ${ }^{6,32}$

A proof base exists for the primary treatments employed for pediatric/children's asthma exacerbations; however, more limited evidence exists for second-line treatments (Table 2). The examination must not delay children treated with an acute asthma exacerbation. Such elements are usually implemented through various team organs at 
an equal time..$^{29,30}$ For children should be used huge flow oxygen of a snugly-fitting face mask with $\mathrm{SpO} 2 \%<94 \%$ or life-threatening (LT) asthma. The saturation of oxygen should reach a rate of $94 \%$ to $98 \%$ (BTS/SIGN 2016). The first-line therapy in children for breathing $\beta 2$ agonist salbutamol is duration of above two years. $\beta 2$ agonists do quickly and the results might take long four to six hours. ${ }^{31}$ Therapeutic answers to $\beta 2$ agonists can be observed utilizing saturations of oxygen and advances in clinical investigations, such as heart rate normalization, respiratory rate normalization, and oxygen saturation. $\beta 2$ agonists are best supplied with a PMDI and spacer and a weak answer recommends the reevaluatio. ${ }^{31}$ The oxygenmade nebulized salbutamol is usually indicated at regular periods for children suffering with life-threatening or acute asthma. A reduced answer shows the requirement for additional measures at 10-min intervals (20-30min). In case of unacceptable reaction to salbutamol at the primary presentation, Ipratropium bromide can be added. ${ }^{31}$ Some researchers have inquired the application of constant $\beta 2$ agonist nebulization with salbutamol in a comparison to intermittent practice among children and thus, continuous type of nebulization is not routinely practiced in the United Kingdom. ${ }^{6,33}$

Potent evidence exists based on the ipratropium bromide treatment at intervals of $20-30 \mathrm{~min}$ in the beginning couple of hours from a severe asthma assault for an extra treatment. ${ }^{31}$ The utilization of ipratropium bromide might decrease rates of hospitalization and recover the performance of the lung while currently used with a $\beta 2$ agonist through the beginning hours of treatment. ${ }^{6,34}$ In a study was discovered that nearly $44 \%$ of centers utilized ipratropium quickly with a $38.7 \%$ doing it after if the primary application of salbutamol showed a weak response. ${ }^{6,32}$ The initial usage of oral administration steroids is advised for acute-type asthma cases, prednisolone is the opted steroid which frequently takes different hours for action. ${ }^{31}$. Steroids can lower the relapse risk and the admission need. IV hydrocortisone should be considered for children suffering with acute asthma or the children who showed no effective response on oral medicine. ${ }^{34}$ Antibiotics are not recommended to be utilized in asthma exacerbations as most maximum is occurred by viral infections, however, a BTS audit concluded that $28 \%$ of the children or teenagers suffering with exacerbations use antibiotics. ${ }^{6}$ Nebulized magnesium sulfate serves as a fast bronchodilator, although the clinical effectiveness of such a drug has still been unknown. ${ }^{6,35}$ Although there is not any data for the control of nebulized magnesium sulfate in mild to medium asthma worsening cases, the guidelines of BTS/SIGN indicate that there might be some benefits to the children holding severe asthma symptoms which exhibit oxygen saturations of $<92 \%$, however, extra investigations are needed. First-line control can be reviewed as treatment of hypoxia, administration of nebulized $\beta 2$ agonists (i.e. salbutamol), oral corticosteroids (i.e. prednisolone), ipratropium bromide and reassessment. The development of second-line treatments is required. The mechanisms and suggestions of these drugs are briefly presented in Table 3. Among children suffering with acute asthma or status asthmaticus for whom maximum optimal cure has been applied, or the children holding such life-threatening symptoms, a pediatrician is needed in order to guide patients experiencing second-line treatments in a care system which is either high dependency or pediatric intensive. Second-line treatments include such intravenous medications as aminophylline, salbutamol, and magnesium sulfate. Additional investigations are required to assess the utility of non-invasive ventilation. ${ }^{6}$

\section{Clinical guidelines for Emergency Departments treatment for children below 5 years}

Due to limited or absent evident base, a specific issue of children under 5 years is guidelines of asthma management ${ }^{36,37}$. Two particular problems exist in this age: 1) absence of suitable objective tests for guidance of either prescription of diagnosis among the children below 5 years old; 2) the heterogeneous asthma pattern among preschool children and different from what os applied for adults. Asthma or wheezing attacks are activated through viral infections ('colds') and mostly, no asthma symptom exists between attacks. The most current pattern ('phenotype') exists up to the age of 3 following to which common interval symptoms of chronic asthma will get more evident. ${ }^{37}$ Both BTS/SIGN and NICE emphasize that plenty of children below 5 years old with recurrent episodes of viral-induced wheezing will not lead to catch chronic asthma. None of the guidelines provides us with instructions regarding the child experiencing frequent wheezing attacks which are treated by oral corticosteroids short courses, but do not have any interval asthma symptoms. ${ }^{37}$

\section{Discharge from emergency ward}

The patients discharged from an emergency ward need specific instructions of asthma discharge which determine what new medications should be taken by patients and what medications are required to continue while the primary care provider is followed up. ${ }^{23,38}$ One of the problems of emergency physicians is the question "whether to begin ICS for discharged patients or not", while the guidelines recommend to consider adding an ICS for patients treated for the acute exacerbation. ${ }^{20}$. The US guidelines propose to apply stepwise treatment according to the careful patient age consideration, asthma-control level categorization, impairment and risk. $^{20}$ The guidelines, as well as advocate for the preparation of a written AAP, including a considerable advice for adding an ICS administration for the children discharged followed by acute care in the emergency ward. ${ }^{23}$ About $67 \%$ percent of children suffering with asthma, and referred to an emergency ward, are classified with persistent asthma, while lower than $10 \%$ were commanded an ICS subsequent to emergency ward 


\section{Pediatric asthma exacerbation in emergency department}

Eur J Trans1 Myol 30 (1): xx1-xx8, 2020

visit. $^{23,39,40}$. The benefits of ICS asthma treatment involve reducing the death risk of asthma, ${ }^{41}$ and a relapse reduction rate of $45 \%$ in comparison to ICS nonusers. ${ }^{23,42}$. Adherence of provider to guidelines of NHLBI in an urban clinic for children with above 3,500 patients showed diminished percentages of hospitalization rates and emergency visits for treatment of asthma. ${ }^{23}$ Though the most of the emergency physicians/clinicians believe that patients with persistent asthma must be treated by controller medications, ${ }^{43}$ emergency visits do not usually occur in prescription alteration for chronic or sub-acute asthma administration. Alternately, emergency providers typically rely on the patient to follow-up with a specialist of primary care. ${ }^{23,39,44}$ The most pediatricians $(80 \%)$ have used the fundamental controller medications throughout the emergency ward appointment, with benefits of providing controller treatment for those who are "lost to follow-up" and forcing the adherence importance to medications of controller; worries mentioned included time deficiency for training in the emergency setting, problem to choose the proper controller according to level of asthma-control, the reinforcement ED possibility utilization instead of the primary care office, lacking any connection with physician of the primary care about the medication, and also the plan for discharge. ${ }^{23,45}$ Another point that narrows the preparation of ICS is the effectiveness of managed care plans which need to precede authorization to apply ICS factors. This is a distinguishing factor in patients not taking decent management because the ED physician does not have the time or the required continuity-care documentation required to take patient's previous authorization in order to achieve suitable control and management. ${ }^{23,46}$

Delivering evidence-based asthma-discharge care in an emergency ward deals with characterizing the contemporary asthma-control level of the patient and administering suitable treatment approach based on particular control-level group which was specified in the visit. This is a complicated, vibrant, and multistep obligation to be employed and work in a busy emergency ward, as such a position has some challenges regarding contemporary signs, prior exacerbations, including hospitalizations, emergency visits, and concomitant medicines. A well-planned study on randomized controlled trials assessing the efficiency of a Written AAP (WAAP) against none concluded that usage of a symptom-based method significantly reduces children's visit for critical care of asthma. ${ }^{23,47}$ The requirement of a WAAP after ED visits for asthma was observed to significantly raise adherence of the patient to commanded acute and controller medicines, as well as asthma control. ${ }^{23,48}$ Nevertheless, a retrospective-type review of children referring to an urban emergency department specific for children concluded that a WAAP was not fixed in a visiting rate of $80 \%$. The preparation of a personalized and electronically created WAAP accommodates the patient and family with knowledge on their contemporary asthma care and provides ED physicians and subspecialists with honest, prompt communication of discharge advice through visiting the patients who follow-up. The demand for a WAAP created in the emergency ward is revealed to be in the fluctuating rates of $7 \%-44 \%$ for pediatric asthma follow-up after ED visits. ${ }^{23,50}$

\section{Conclusions}

Performing the most suitable health care plans for the administration of Pediatric Asthma needs a multidisciplinary method in any management phase. After the primary assessment, quick diagnosis, clinical practice guidelines are useful tools for the proper management of pediatric Asthma. By setting the proper guidelines for taking the most efficient outcomes for this particular population, a higher improvement in the quality of management of clinical practice guidelines of pediatric Asthma will be achieved. Given the diversities and differences between the advices arisen by guidelines of BTS/SIGN and NICE, it will be undeniable that severe inspection of the evidence-base designates that usually more in common exist between the guidelines compared to what might seem initially. It is anticipated that such a test of the variations concentrated in present article will assist the clinicians to make accurate decisions regarding their patients. Our knowledge and experiences regarding the asthma are expanding and thus our evaluation about treatments should be improved as well. More researches to illuminate currently insufficient or missing data is crucially needed so that updates can provide physicians and clinicians with the best possible evidence-based recommendations.

\section{List of acronyms}

AAP - Asthma Action Plan

BTS - British Thoracic Society

EBM - evidence-based medicine

ED - Emergency Department

GIM - Global Index Medicus

ISAAC - International Study of Asthma and Allergies in Childhood

LT - life-threatening

NAEPP - National Asthma Education and Prevention Program

NHLBI - National Heart, Lung, and Blood Institute

NICE - Health and Care Excellence

PCP - Primary Care Provider

PEFR - peak expiratory flow rate

PMDI - pressurized metered-dose inhaler

SABA - Short Acting $\beta$-Agonist

SIGN - Scottish Intercollegiate Guideline Network

\section{Author's contributions}

Both authors played a substantial role in data acquisition and analysis, and also in conception and revision of the manuscript.

\section{Acknowledgments}

None. 


\section{Pediatric asthma exacerbation in emergency department}

Eur J Transl Myol 30 (1): xx1-xx8, 2020

Funding There was no funding support for this study.

\section{Conflict of Interest}

The authors have no conflicts to disclose.

\section{Ethical Publication Statement}

We confirm that we have read the Journal's position on issues involved in ethical publication and affirm that this report is consistent with those guidelines.

\section{Corresponding Author}

Hamidreza Khoshnezhad Ebrahimi, Department of Emergency Medicine, School of Medicine, Iran University of Medical Sciences, Aliasghar children Hospital, Tehran, Iran

Tel :+98-21-22222041

Email: khoshnezhad.hr@iums.ac.ir

E-mails of co-author

Shabahang Jafarnejad: jafarnejad.sh@iums.ac.ir

\section{References}

1. Control CFD. Vital Signs: Asthma Prevalence, Disease Characteristics, and Self-Management Education -- United States, 2001-2009.Centers for Disease Control and Prevention 2011;60;547-52.

2. Bateson TF, Schwartz J. Children's response to air pollutants. Journal of Toxicology and Environmental Health, Part A, 2007;71:238-43.

3. Bloom B, Jones LI, Freeman G. Summary health statistics for U.S. children: National Health Interview Survey, 2012. Vital Health Stat 10. 2013;258:1-81.

4. Akinbami LJ, Moorman JE, Liu X. Asthma prevalence, health care use, and mortality; United States, Natl Health Stat Report 2011;32:1-14.

5. Grimshaw JM, Eccles MP, Walker AE, et al. Changing physicians' behavior: what works and thoughts on getting more things to work. J Contin Educ Health Prof 2002;22:237-43.

6. Sheldon G, Anthony Heaton P, Palmer S, et al., Nursing management of paediatric asthma in emergency departments. Emerg Nurse 2018;26:3242.

7. Health NI. National asthma education and prevention program. Expert panel report 1997.p. 3.

8. Ellwood P, Asher MI, Beasley R, et al., The International Study of Asthma and Allergies in Childhood (ISAAC): Phase Three rationale and methods [Research Methods]. Int J Tuberc Lung Dis 2005;9:10-6.

9. Weiland SK, Björkstén B, Brunekreef B, et al., Phase II of the International Study of Asthma and Allergies in Childhood (ISAAC II): rationale and methods. Eur Respir J 2004;24:406-12.

10. Asher MI, Keil U, Anderson HR, et al., International Study of Asthma and Allergies in Childhood (ISAAC): rationale and methods. Eur Respir J 1995;8:483-91.
11. Asher MI, Montefort S, Björkstén B, et al., Worldwide time trends in the prevalence of symptoms of asthma, allergic rhinoconjunctivitis, and eczema in childhood: ISAAC Phases One and Three repeat multicountry cross-sectional surveys. Lancet 2006;368:733-43.

12. Loftus PA, Wise SK. Epidemiology and economic burden of asthma. in International forum of allergy \& rhinology. 2015. Wiley Online Library.

13. Pollock J, Shi L, Gimbel RW. Outdoor environment and pediatric asthma: an update on the evidence from North America. Can Respir J 2017;2017:8921917.

14. Turner S. Predicting and reducing risk of exacerbations in children with asthma in the primary care setting: current perspectives. Pragmat Obs Res 2016;7:33-9.

15. Foy AJ, Liu G, Davidson WR Jr, et al., Comparative effectiveness of diagnostic testing strategies in emergency department patients with chest pain: an analysis of downstream testing, interventions, and outcomes. JAMA Intern Med 2015;175:428-36.

16. Gorelick MH, Schremmer R, Ruch-Ross H,et al., Current workforce characteristics and burnout in pediatric emergency medicine. Acad Emerg Med 2016;23:48-54.

17. Remick K, Gausche-Hill M, Joseph MM, et al., Pediatric readiness in the emergency department. Pediatrics 2018:142:e20182459.

18. Bush A, Fleming L. Diagnosis and management of asthma in children. BMJ, 2015;350: h996.

19. Hardinge M, Annandale J, Bourne S, et al., British Thoracic Society guidelines for home oxygen use in adults: accredited by NICE. Thorax 2015;70:i1-i43.

20. Cabana MD, Slish KK, Nan B, et al., Asking the correct questions to assess asthma symptoms. Clin Pediatr (Phila) 2005;44:319-25.

21. Gupta RS, Weiss KB. The 2007 National Asthma Education and Prevention Program asthma guidelines: accelerating their implementation and facilitating their impact on children with asthma. Pediatrics 2009;123: S193-8.

22. Lauer MS, Kiley JP, Mockrin SC, et al., National Heart, Lung, and Blood Institute (NHLBI) strategic visioning: setting an agenda together for the NHLBI of 2025. Circulation 2015;131:1106-9.

23. Johnson LH, Chambers P, Dexheimer JW. Dexheimer, Asthma-related emergency department use: current perspectives. Open Access Emerg Med 2016;8:47-55.

24. National Heart, L. and B. Institute, Expert panel report 3 (EPR3): guidelines for the diagnosis and management of asthma. http://www. nhlbi. nih. gov/guidelines/asthma/, 2007.

25. James DR, Lyttle MD. British guideline on the management of asthma: SIGN Clinical Guideline 141, 2014. Arch Dis Child Educ Pract Ed 2016;101:319-322. 


\section{Pediatric asthma exacerbation in emergency department}

Eur J Transl Myol 30 (1): xx1-xx8, 2020

26. Qureshi F, Pestian J, Davis P, et al., Effect of nebulized ipratropium on the hospitalization rates of children with asthma. $\mathrm{N}$ Engl $\mathrm{J}$ Med 1998;339:1030-5.

27. Turner S, Richardson K, Murray C, et al., Longacting $\beta$-agonist in combination or separate inhaler as step-up therapy for children with uncontrolled asthma receiving inhaled corticosteroids. J Allergy Clin Immunol Pract 2017;5:99-106.e3.

28. Kelly AM, Kerr D, Powell C. Is severity assessment after one hour of treatment better for predicting the need for admission in acute asthma? Respir Med 2004;98:777-81.

29. DiBlasi RM, Cheifetz IM. Neonatal and pediatric respiratory care: what does the future hold?. Respir Care 2011;56:1466-80.

30. Massingham K, Fox S, Smaldone A. Asthma therapy in pediatric patients: a systematic review of treatment with montelukast versus inhaled corticosteroids. J Pediatr Health Care 2014;28:5162.

31. Paul S, Garg A, Garg N. Managing asthma in children: a flexible approach. British J Family Med 2014: 4:28-31.

32. Lyttle MD, O'Sullivan R, Doull I, et al., Variation in treatment of acute childhood wheeze in emergency departments of the United Kingdom and Ireland: an international survey of clinician practice. Arch Dis Child 2015;100:121-5.

33. Camargo CA Jr, Spooner $\mathrm{CH}$, Rowe $\mathrm{BH}$. Continuous versus intermittent beta-agonists for acute asthma. Cochrane Database Syst Rev. 2003;CD001115.

34. Ortiz-Alvarez O, Mikrogianakis A. Managing the paediatric patient with an acute asthma exacerbation. Paediatr Child Health 2012;17:25162.

35. Schuh S, Sweeney J, Freedman SB, et al., Magnesium nebulization utilization in management of pediatric asthma (MagNUM PA) trial: study protocol for a randomized controlled trial. Trials 2016;17:261.

36. Mark NA. A structured approach is key to diagnosing asthma By Professor Hilary Pinnock 2016:12:18-22.

37. White, J, Paton J, Niven R, et al., Guidelines for the diagnosis and management of asthma: a look at the key differences between BTS/SIGN and NICE. Thorax 2018:73:293-7.

38. Rowe BH, Villa-Roel C, Majumdar SR, et al., Rates and Correlates of Relapse Following ED Discharge for Acute Asthma. Chest 2015;147:140-9.

39. Arellano FM, Arana A, Wentworth CE, et al., Frequency of prescription of inhaled corticosteroids to children with asthma in US emergency departments. Pediatr Allergy Immunol. 2011;22:469-76.

40. Walsh-Kelly CM, Kelly KJ, Drendel AL, et al., Emergency department revisits for pediatric acute asthma exacerbations: association of factors identified in an emergency department asthma tracking system. Pediatr Emerg Care. 2008;24:50510.

41. Croisant S, Epidemiology of asthma: prevalence and burden of disease, in Heterogeneity in asthma. 2014:17-29.

42. Sin DD, Man SP. Low-dose inhaled corticosteroid therapy and risk of emergency department visits for asthma. Archives Inter Med 2002;162: 1591-5.

43. Scarfone RJ, Zorc JJ, Angsuco CJ. Emergency physicians' prescribing of asthma controller medications. Pediatrics 2006:117:821-7.

44. Lovinsky S,Rastogi D. Prescription habits for preventative medications among pediatric emergency department physicians at an inner-city teaching hospital. J Asthma 2010;47:1011-4.

45. Sampayo EM, McLoughlin RJ, Tsevdos D, et al. Pediatricians support initiation of asthma controller medications in the emergency department: a national survey. Pediatr Emerg Care 2015;31:54550.

46. Meltzer EO, Shaikh A, Engel M, et al. Effect Of Tiotropium Respimat ${ }^{\circledR} 2.5 \mu \mathrm{g}$ Add-On To ICS Or ICS+ Controller Medications On Clinical Outcomes In Adults And Adolescents With Asthma Across Severities. Therapeutic trials in asthma. 2017:A3183.

47. Matsui EC, Wood RA. Low-dose inhaled corticosteroid therapy and risk of emergency department visits for asthma. Pediatrics, 2003;112:483.

48. Ducharme FM, Zemek RL, Chalut D, et al. Written action plan in pediatric emergency room improves asthma prescribing, adherence, and control. Am J Respir Crit Care Med 2011;183:195-203.

49. Baren JM, Shofer FS, Ivey B, et al. A randomized, controlled trial of a simple emergency department intervention to improve the rate of primary care follow-up for patients with acute asthma exacerbations. Ann Emerg Med 2001;38:115-22.

50. Ly CD, Dennehy CE. Emergency department management of pediatric asthma at an university teaching hospital. Ann Pharmacother 2007;41:1625-31.

Submission: November, 15, 2019

Acceptance: December 8, 201 